\title{
Risk factors for Toxoplasma gondii infection in sheep and cattle from Fernando de Noronha Island, Brazil
}

\begin{abstract}
Fatores de risco para infecção por Toxoplasma gondii em ovinos e bovinos na Ilha de Fernando de Noronha, Brasil

Fernando Jorge Rodrigues Magalhães ${ }^{1}$; Müller Ribeiro-Andrade²; Adrianne Mota de Alcântara²; José Wilton Pinheiro Júnior²; Maria José de Sena²; Wagnner José Nascimento Porto ${ }^{3}$; Rafael Felipe da Costa Vieira ${ }^{4}$; Rinaldo Aparecido Mota ${ }^{2 *}$

${ }^{1}$ Unidade de Vigilância em Saúde, Fernando de Noronha, PE, Brasil

${ }^{2}$ Departamento de Medicina Veterinária, Universidade Federal Rural de Pernambuco - UFRPE, Recife, PE, Brasil

${ }^{3}$ Unidade Educacional Viçosa, Universidade Federal de Alagoas - UFAL, Campus Arapiraca, Viçosa, AL, Brasil

${ }^{4}$ Departamento de Medicina Veterinária, Universidade Federal do Paraná - UFPR, Curitiba, PR, Brasil

Received April 18, 2016

Accepted June 17, 2016

Abstract

Toxoplasmosis is a zoonotic disease of global distribution that affects all warm-blooded animals. The purpose of this investigation was to determine the prevalence of $T$. gondii infection and identify the risk factors associated with its occurrence in domestic ruminants raised on the island of Fernando de Noronha, Brazil, and to confirm that cattle and sheep raised in Fernando de Noronha Island present statistically different $T$. gondii prevalence rates. Serum samples were collected from sheep $(n=240)$ and cattle $(n=140)$ for the detection of antibodies by indirect immunofluorescence. Samples were collected from all the animals on all the farms. Risk factors were analyzed by univariate analysis and logistic regression. The prevalence rate of positive sheep was $85.0 \%$ while that of cattle was $10.7 \%$. A multivariate analysis revealed that the site of contact of sheep with felines was a risk factor. For cattle, the risk factors identified in this study were: extensive farming system, water source, more than three cats per farm, and the presence of rats in feed storage locations. The findings revealed a significant difference in the prevalence rates in sheep and cattle raised in this insular environment.
\end{abstract}

Keywords: Ruminants, toxoplasmosis, epidemiology.

\section{Resumo}

A toxoplasmose é uma zoonose cosmopolita que acomete animais de sangue quente. Objetivou-se nessa investigação determinar a prevalência e identificar os fatores de risco associados à ocorrência da infecçáo por $T$. gondii em ruminantes domésticos criados na Ilha de Fernando de Noronha e demonstrar que bovinos e ovinos criados na ilha de Fernando de Noronha, Brasil, apresentam prevalências estatisticamente distintas. Foram obtidas amostras de soro sanguíneo de todos os ovinos $(\mathrm{n}=240)$ e bovinos $(\mathrm{n}=140)$ de todas as propriedades da ilha para a pesquisa de anticorpos na Reação de Imunofluorescência Indireta. Os fatores de risco foram analisados por meio da análise univariada e regressão logística. A prevalência de ovinos reagentes foi de 85,0\% e 10,7\% para bovinos, que foram significativamente diferentes. Na análise multivariada, local de contato de ovinos com outras espécies foi identificado como fator de risco. Para os bovinos, os fatores de risco foram: sistema extensivo, fonte de água, número de gatos nas propriedades e a presença de rato. Os resultados obtidos demonstram diferença significativa nas prevalências em ovinos e bovinos criados neste ambiente insular.

Palavras-chave: Ruminantes, toxoplasmose, epidemiologia.

\footnotetext{
*Corresponding author: Rinaldo Aparecido Mota. Departamento de Medicina Veterinária, Universidade Federal Rural de Pernambuco - UFPE, Rua Dom Manoel de Medeiros, s/n, Dois Irmãos, CEP 52171-900, Recife, PE, Brasil. e-mail: rinaldo.mota@hotmail.com
} 


\section{Introduction}

The island of Fernando de Noronha (state of Pernambuco, Brazil) is located in the South Atlantic. Since it was first colonized, the island has undergone changes brought about by humans and by the introduction of non-native species, such as domestic cats, which pose a threat to biodiversity conservation in insular regions (KAISER, 2001) and can trigger impacts associated with diseases, such as toxoplasmosis (TENTER et al., 2000).

Toxoplasmosis is one of the world's most widespread zoonotic diseases that affect a variety of warm-blooded mammal and bird species (TENTER et al., 2000; DUBEY, 2010). T. gondii reproduces sexually only in cats, which eliminate millions of oocysts in their feces. After they sporulate, these oocysts contaminate soil, water sources and food, constituting an important source of infection for their intermediate hosts (DUBEY, 2010).

Small ruminants such as sheep may present reproductive changes that lead to significant economic losses for the food production chain (BUXTON et al., 2007). Cattle also become infected, but they are considered more resistant to $T$. gondii, and the importance of these animals in the epidemiology of toxoplasmosis is still a controversial issue (DUBEY, 1986, 2010; DUBEY \& JONES, 2008).

Costa et al. (2012) demonstrated that domestic animals such as cattle and sheep on the island of Fernando de Noronha have antibodies against $T$. gondii, but they did not examine the risk factors and the spatial distribution of toxoplasmosis on this island. The purpose of this study was therefore to study the prevalence of Toxoplasma gondii infection in sheep and cattle and to identify risk factors associated with infection by T. gondii in domestic ruminants raised on the island of Fernando de Noronha, Brazil, as well as to confirm that, although they live in the same environment, these ruminants present different levels of infection.

\section{Materials and Methods}

\section{Ethics committee}

The procedures in this experiment were approved by the Ethics Committee for Animal Use (CEUA) of the Federal University of Pernambuco under protocol number 004/2016, and are in accordance with the current guidelines of the Brazilian College of Animal Experimentation (COBEA).

\section{Area of study and sampling}

Fernando de Noronha Island is located in the state of Pernambuco, northeastern of Brazil, comprises 21 islands and islets and is focused on the preservation of wildlife. The main island, Fernando de Noronha, has an area of approximately $17.017 \mathrm{~km}^{2}$. The Island has a population of 2,930 residents.

The animals involved in this study were 240 sheep on eight farms and 140 head of cattle on ten farms (Table 1). Samples were collected from all the animals on all the farms.

\section{Collection of blood samples}

Blood samples were drawn from both sexes by jugular (sheep) and coccygeal venipuncture (cattle). The blood samples were immediately refrigerated and sent to the Laboratory of the Animal Health Surveillance Center of the State District of Fernando de Noronha for centrifugation and blood serum preparation, after which they were frozen and sent by air to the Laboratory of Infectious Diseases at the Federal Rural University of Pernambuco, where they were processed.

\section{Serological analysis}

Serum samples were subjected to the indirect fluorescence antibody test (IFAT) to detect anti- $T$. gondii IgG antibodies. The slides were coated with tachyzoites of the RH strain of

Table 1. Absolute and relative frequency of sheep and cattle positive and negative for anti-Toxoplasma gondii antibodies by IFAT, according to location on Fernando de Noronha Island, Brazil.

\begin{tabular}{|c|c|c|c|c|c|c|c|}
\hline \multirow{2}{*}{ Animals } & \multirow{2}{*}{ Location } & \multirow{2}{*}{$\begin{array}{l}\text { No. of } \\
\text { Farms }\end{array}$} & \multirow{2}{*}{$\begin{array}{c}\text { No. of } \\
\text { samples }\end{array}$} & \multicolumn{2}{|c|}{ Positive } & \multicolumn{2}{|c|}{ Negative } \\
\hline & & & & AF & RF (\%) & AF & RF (\%) \\
\hline \multirow{6}{*}{ Sheep } & Floresta Velha & 1 & 4 & 3 & 75.00 & 1 & 25.00 \\
\hline & Vila dos Remédios & 1 & 5 & 3 & 60.00 & 2 & 40.00 \\
\hline & Vila dos Três Paus & 1 & 90 & 84 & 93.30 & 6 & 6.70 \\
\hline & Vila da Basinha & 1 & 15 & 12 & 80.00 & 3 & 20.00 \\
\hline & Vila da Coréia & 2 & 48 & 40 & 83.30 & 8 & 16.70 \\
\hline & Estrada Velha do Sueste & 2 & 78 & 62 & 79.49 & 16 & 20.51 \\
\hline \multirow{6}{*}{ Cattle } & Floresta Nova & 1 & 9 & 0 & 0.0 & 9 & 100.0 \\
\hline & Floresta Velha & 1 & 27 & 3 & 11.0 & 24 & 89.0 \\
\hline & Vila dos Três Paus & 4 & 38 & 9 & 23.0 & 29 & 74.0 \\
\hline & Vila da Basinha & 1 & 2 & 0 & 0.0 & 2 & 100.0 \\
\hline & Vila do Sueste & 1 & 12 & 0 & 0.0 & 12 & 100.0 \\
\hline & Estrada Velha do Sueste & 2 & 52 & 3 & 6.0 & 49 & 94.0 \\
\hline
\end{tabular}


T. gondii, using a specific anti-IgG antibody for the animal species conjugated with fluorescein isothiocyanate (Sigma-Aldrich Co., St. Louis, USA), A cut off point of 1:64 was adopted for sheep and cattle (GARCIA et al., 1999; DUBEY, 2010), and positive samples were diluted to a ratio of two and their titers determined by positive reaction of the highest dilution. Positive and negative controls were included in all the reactions.

\section{Risk analysis}

The chi-square test with a $95 \%$ significance level was used to evaluate the statistical difference between the prevalence rates in the species under study.

For the study of risk factors associated with $T$. gondii infection, questionnaires were applied containing objective questions about to the animal production and health management and about toxoplasmosis epidemiology. The questionnaires were applied by a single person trained specifically for this purpose.

Initially, the variables were evaluated by univariate analysis, using Pearson's chi-square test or Fisher's exact test, when necessary, and adopting a $95 \%$ confidence interval. In a second stage of analysis, the variables with $p \leq 0.2$ in univariate analysis were selected for logistic regression model considered as dependent variable the serological results (reagent or non-reagent), and the calculations were performed using the EpiInfo version 3.5.2 program - Centers for Disease Control and Prevention (CDC).

\section{Spatial distribution}

The plane coordinates obtained by georeferencing each farm using a global positioning system (GPS) were used to spatialize the map of Fernando de Noronha Island, which was configured to pinpoint the positions with plane coordinates in UTM (Universal Transverse Mercator) projection in the SAD-69 System (South American Datum 1969), corresponding to the cartographic coordinate system of the Fernando de Noronha Island. The georeferenced data were entered into the ArcGIS 10.2 software program using the Kernel intensity estimator, which is a non-parametric technique that enables the variability of a set of data to be filtered, retaining the essential local characteristics of the data (BAILEY \& GATRELL, 1995).

\section{Results}

The prevalence of sheep positive for T. gondii in Fernando de Noronha Island was 85.0\% (204/240, 79.8-89.3\%, CI 95\%). Among the different regions of the archipelago, the highest prevalence, 93.3\%, was observed in Vila dos Três Paus, and the lowest, $60.0 \%$, in Vila dos Remédios (Table 1). For cattle, the prevalence was $10.7 \%(15 / 140)$, ranging from $0 \%$ to $23.0 \%$ among the different regions of the island (Table 1 ). The prevalence rates of the two species showed a statistically significant difference $(\mathrm{p}=0.000)$.

Figures 1A, B, respectively, show the Kernel estimate for the number of sheep and cattle seropositive for $T$. gondii in the archipelago. The color gradient quantifies the density of cases per farm (green: lowest prevalence; red: highest prevalence).

The univariate analysis for sheep showed a significant association between $T$. gondii infection and the following variables: sex $(p=0.007)$; location of the farm $(p=0.024)$; site of contact with feline $(p=0.046)$; water supply $(p=0.019)$; and number of domestic cats $(p=0.019)$. In the logistic regression (Table 2$)$, the site of contact with feline was identified as a risk factor, $\mathrm{OR}=2.94$.

For cattle, the univariate analysis revealed a significant association between $T$. gondii infection and the following variables: type of farming system $(\mathrm{p}=0.002)$; water supply $(\mathrm{p}=0.000)$; number of domestic cats $(p=0.002)$; access of cats to animal feed $(p=0.000)$; presence of feral cats on the farms $(\mathrm{p}=0.044)$; and access of rats to animal feed $(\mathrm{p}=0.000)$. The following risk factors were identified by logistic regression: extensive farming system $(\mathrm{OR}=6)$, water supply (pond) $(\mathrm{OR}=8.36)$, number of domestic cats $(>3)(\mathrm{OR}=5.76)$, and access of rats to animal feed $(\mathrm{OR}=7.62)$ (Table 2).

\section{Discussion}

This work involves a comprehensive investigation of T. gondii infection in domestic ruminants in Fernando de Noronha Island, since all the sheep and cattle raised on this island were sampled,
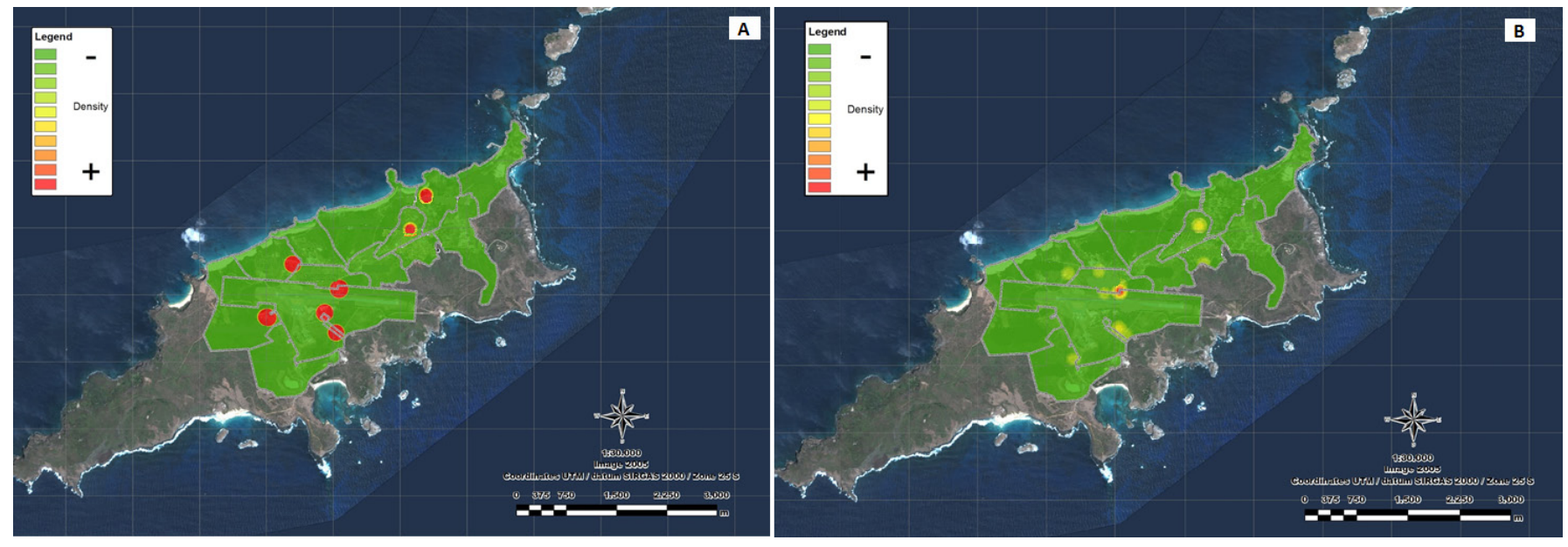

Figure 1. Kernel estimation map of the prevalence of Toxoplasma gondii infection in sheep (A) and cattle (B) from Fernando de Noronha Island. 
Table 2. Logistic regression analysis of risk factors associated with Toxoplasma gondii infection in sheep and cattle from Fernando de Noronha Island, Brazil.

\begin{tabular}{clccc}
\hline Animals & \multicolumn{1}{c}{ Variable } & p-value & OR & CI 95\% \\
\hline \multirow{2}{*}{ Sheep } & Location of contact with feline (Pasture + facilities) & 0.000 & 2.94 & $1.23-7.05$ \\
& Extensive system & 0.004 & 6.63 & $1.78-24.72$ \\
& Water supply (reservoir) & 0.000 & 8.36 & $2.66-26.23$ \\
\multirow{2}{*}{ Cattle } & Number of cats (more than 3) & 0.009 & 5.76 & $1.53-21.66$ \\
& Presence of rats in animal feed & 0.002 & 7.62 & $2.04-28.49$ \\
\hline
\end{tabular}

OR - Odds ratio; CI - Confidence interval.

unlike another study involving cattle and sheep conducted previously at this location (COSTA et al., 2012), which did not include spatial distribution or risk factor analysis. These animals were introduced into this archipelago in the early 20th century and have had no contact with animals on the continent, thus constituting a population of animals with specific genetics and management characteristics, which are used by local families to supply milk and meat for their subsistence (PERNAMBUCO, 2015).

An analysis of the Kernel estimation maps for T. gondii infection in cattle and sheep on the Fernando de Noronha Island indicates that foci of infection are scattered throughout the island where these animals are raised.

Various studies around the world have demonstrated the exposure of sheep and cattle to T. gondii (DUBEY, 2010), but few studies have been conducted on oceanic islands around the world. This comprehensive study in this location was facilitated by the easy access to the island and by contact with the local animal health authorities.

The prevalence of positive sheep (85.0\%, 79.8-89.3\%; CI 95\%) in Fernando de Noronha Island was found to be higher than the prevalence rates found in surveys in continental Brazil, which reported a variation of $7 \%$ (MOURA et al., 2007) a 51.8\% (GARCIA et al., 1999). Surveys in the Caribbean islands of Dominica, Grenada, Montserrat, St. Kitts and Nevis (HAMILTON et al., 2014) and Carriacou (CHIKWETO et al., 2011) also found high T. gondii infection rates ranging from $44.1 \%$ to $89 \%$. The authors attribute this case, a higher prevalence in island environment due to the high concentration of cats, especially those of feral habits that are not subjected to any health care and when infected by $T$. gondii contaminate the environment with oocysts, serving as a source of infection to livestock.

As for bovines, studies in different regions of Brazil showed values ranging from 1\% in Bahia (GONDIM et al., 1999) to 71\% in Mato Grosso (SANTOS et al., 2009). The prevalence found in the Island $(10.7 \% ; 6.1-17.1 \%$; CI $95 \%)$ is similar to findings on other oceanic islands reported by Chikweto et al. (2011), who found a positivity rate of $8.4 \%$ among the cattle in the Caribbean islands of Grenada and Carriacou.

The exposure of domestic and wild animals to $T$. gondii on Fernando de Noronha Island was the subject of only one previous investigation, which reported a positivity rate of 3.0\% (3/100) among cattle and of $60.8 \%$ (59/97) among sheep (COSTA et al., 2012). As can be seen, therefore, the prevalence of $T$. gondii infection in these species has increased, which may be attributed to greater environmental contamination by oocysts of coccidia, since the cat population on this island, especially of stray cats, has increased by more than $40 \%$ in recent years.

In general, the prevalence of $T$. gondii in farm animals is higher in sheep than in cattle (DUBEY, 2009, 2010), and may be associated with the resistance of cattle to infection (TENTER et al., 2000; DUBEY, 2010) and with the feeding habits of these animals. Sheep tend to graze on shorter grasses closer to the ground, and are therefore more susceptible to oocyst ingestion than cattle, which feed on the higher portions of fodder grasses (ANDRIGUETTO, 1983).

In the present study, the sheep raised in contact with feline on pasture and in confined animal facilities presented a 2.94-fold greater likelihood of becoming infected by $T$. gondii than those in contact with feline only on pasture. This may indicate the extensive contamination of production areas (both pasture and confinement facilities) with oocysts of $T$. gondii, thus requiring the adoption of sanitary measures for control and prevention on farms. Costa et al. (2012) reported that $66.6 \%$ of feral cats and $54.2 \%$ of domestic cats on this island were positive for $T$. gondii, and also found that positivity increases as these animals become older.

According to Dubey (2009), few studies have examined the risk factors associated with the exposure of sheep to this protozoan. Moreover, albeit not statistically significant in this study, the presence of cats on the farms (VESCO et al., 2007), the source of water consumed by the animals (ROMANELLI et al., 2007), and the adoption of extensive farming (ABU SAMRAA et al., 2007) are factors that have been associated with seropositivity for T. gondii in sheep in other investigations.

The risk factors associated with seropositivity for $T$. gondii in cattle in this study were: animals raised in extensive farming system $(\mathrm{OR}=6.63$; CI 95\% - 1.78-24.72), use of reservoir as water supply $(\mathrm{OR}=8.36$; CI 95\% 2.66-26.23), presence of more than three domestic cats on the farm $(\mathrm{OR}=5.76$; CI 95\% - 1.53-21.66), and access of rats to the animal feed (OR=7.62; CI 95\% - 2.04-28.49). These results are consistent with the findings of Albuquerque et al. (2011) and Fajardo et al. (2013), who also identified the risk of infection by $T$. gondii associated with the number of cats. Even with the adoption of population control measures by the Administration of the State District of Fernando de Noronha, such as a cat neutering program, the number of feral cats on the island has grown in recent years. The presence of rodents on these farms is also a factor of attraction for cats that prey on these animals, contributing to increase the proximity between the definitive hosts of T. gondii and farm animals. 
The cattle raised in extensive systems and which use reservoirs for watering presented a higher likelihood of becoming infected with $T$. gondii, because they are more likely to ingest the oocysts of $T$. gondii.

\section{Conclusion}

The results of this study demonstrated that the prevalence of anti-T. gondii antibodies differs significantly in sheep and cattle raised in an insular and highly urbanized environment. The animals raised on this island are exposed to an environment contaminated with oocysts of $T$. gondii. We recommend that the risk factors identified in this study be corrected, and that care be taken in the consumption of beef and mutton raised locally, considering the high prevalence of $T$. gondii found mainly in sheep.

\section{Acknowledgements}

The authors gratefully acknowledge FACEPE (Pernambuco Research Foundation) for its financial support of this work (Process No. APQ-0531-5.05/14).

\section{References}

Abu Samraa N, McCrindle CME, Penzhorn BL, Cenci-Goga B. Seroprevalence of toxoplasmosis in sheep in South Africa. J S Afr Vet Assoc 2007; 78(3): 116-120. http://dx.doi.org/10.4102/jsava.v78i3.301. PMid:18237032.

Albuquerque GR, Munhoz AD, Teixeira M, Flausino W, Medeiros SM, Lopes CWG. Risk factors associated with Toxoplasma gondii infection in dairy cattle, State of Rio de Janeiro. Pesqui Vet Bras 2011; 31(4): 287-290. http://dx.doi.org/10.1590/S0100-736X2011000400003.

Andriguetto JM. Nutrição animal. São Paulo: Nobel; 1983.

Bailey TC, Gatrell AC. Interactive spatial data analysis. Essex: Longman; 1995.

Buxton D, Maley SW, Wright SE, Rodger S, Bartley P, Innes EA. Toxoplasma gondii and ovine toxoplasmosis: new aspects of an old story. Vet Parasitol 2007; 149(1-2): 25-28. http://dx.doi.org/10.1016/j.vetpar.2007.07.003. PMid:17686585.

Chikweto A, Kumthekar S, Tiwari K, Nyack B, Deokar MS, Stratton G, et al. Seroprevalence of Toxoplasma gondii in pigs, sheep, goats, and cattle from Grenada and Carriacou, West Indies. J Parasitol 2011; 97(5): 950-951. http://dx.doi.org/10.1645/GE-2811.1. PMid:21506801.

Costa DGC, Marvulo MFV, Silva JSA, Santana SC, Magalhães FJR, Lima CDF Fo, et al. Seroprevalence of Toxoplasma gondii in domestic and wild animals from the Fernando de Noronha, Brazil. J Parasitol 2012; 98(3): 679-680. http://dx.doi.org/10.1645/GE-2910.1. PMid:22150091.

Dubey JP, Jones JL. Toxoplasma gondii infection in humans and animals in the United States. Int J Parasitol 2008; 38(11): 1257-1278. http:// dx.doi.org/10.1016/j.ijpara.2008.03.007. PMid:18508057.
Dubey JP. A review of toxoplasmosis in cattle. Vet Parasitol 1986; 22(3-4): 177-202. http://dx.doi.org/10.1016/0304-4017(86)90106-8. PMid:3551316.

Dubey JP. Toxoplasmosis in sheep: the last 20 years. Vet Parasitol 2009; 163(1-2): 1-14. http://dx.doi.org/10.1016/j.vetpar.2009.02.026. PMid:19395175.

Dubey JP. Toxoplasmosis of animals and humans. Florida: CRC Press; 2010.

Fajardo HV, D'ávila S, Bastos RR, Cyrino CD, Detoni ML, Garcia $\mathrm{JL}$, et al. Seroprevalence and risk factors of toxoplasmosis in cattle from extensive and semi-intensive rearing systems at Zona da Mata, Minas Gerais State, Southern Brazil. Parasit Vectors 2013; 6(1): 191. http:// dx.doi.org/10.1186/1756-3305-6-191. PMid:23800302.

Garcia JL, Navarro IT, Ogawa L, Oliveira RC. Soroprevalência do Toxoplasma gondii, em suínos, bovinos, ovinos e equinos, e sua correlaçáo com humanos, felinos e caninos, oriundos de propriedades rurais do norte do Paraná - Brasil. Cienc Rural 1999; 29(1): 91-97. http://dx.doi. org/10.1590/S0103-84781999000100017.

Gondim LFP, Barbosa HV, Ribeiro CHA Fo, Saeki H. Serological survey of antibodies to Toxoplasma gondii in goats, sheep, cattle, and water buffaloes in Bahia State, Brazil. Vet Parasitol 1999; 82(4): 273-276. http://dx.doi.org/10.1016/S0304-4017(99)00033-3. PMid:10384902.

Hamilton CM, Katzer F, Innes EA, Kelly PJ. Seroprevalence of Toxoplasma gondii in small ruminants from four Caribbean islands. Parasit Vectors 2014; 7(1): 449. http://dx.doi.org/10.1186/1756-3305-7-449. PMid:25249175.

Kaiser J. Galápagos takes aim at alien invaders. Science 2001; 293(5530): 590-592. http://dx.doi.org/10.1126/science.293.5530.590. PMid:11474079.

Moura AB, Osaki SC, Zulpo DL, Marana ERM. Ocorrência de anticorpos contra Toxoplasma gondii em suínos e ovinos abatidos no município de Guarapuava, PR, Brasil. Rev Bras Parasitol Vet 2007; 16(1): 54-56. PMid: 17588324

Pernambuco. Governo do Estado. Fauna do Arquipélago de Fernando de Noronha [online]. 2015 [cited 2015 Nov 20]. Available from: http:// www.noronha.pe.gov.br/

Romanelli PP, Freire RL, Vidotto O, Marana ERM, Ogawa L, De Paula VSO, et al. Prevalence of Neospora caninum and Toxoplasma gondii in sheep and dogs from Guarapuava farms, Paraná State. Res Vet Sci 2007; 82(2): 202-207. http://dx.doi.org/10.1016/j.rvsc.2006.04.001. PMid:17266999.

Santos TR, Costa AJ, Toniollo GH, Luvizotto MC, Benetti AH, Santos RR, et al. Prevalence of anti-Toxoplasma gondii antibodies in dairy cattle, dogs, and humans from the Jauru micro-region, Mato Grosso state, Brazil. Vet Parasitol 2009; 161(3-4): 324-326. http://dx.doi.org/10.1016/j. vetpar.2009.01.017. PMid:19232473.

Tenter AM, Heckeroth AR, Weiss LM. Toxoplasma gondii: from animals to humans. Int J Parasitol 2000; 30(12-13): 1217-1258. http://dx.doi. org/10.1016/S0020-7519(00)00124-7. PMid:11113252.

Vesco G, Buffolano W, La Chiusa S, Mancuso G, Caracappa S, Chianca A, et al. Toxoplasma gondii infections in sheep in Sicily, southern Italy. Vet Parasitol 2007; 146(1-2): 3-8. http://dx.doi.org/10.1016/j. vetpar.2007.02.019. PMid:17383099. 